\title{
The ovary and its genes-developmental processes underlying the establishment and function of a highly divergent reproductive system in the female castes of the honey bee, Apis mellifera
}

\author{
Klaus Hartfelder ${ }^{1}$, Gustavo Jacomini TiBerio ${ }^{1}$, Denyse Cavalcante LAGo ${ }^{1}$, \\ Rodrigo Pires Dallaceua ${ }^{2}$, Marcia Maria Gentile Bitondi ${ }^{3}$
${ }^{1}$ Departamento de Biologia Celular e Molecular e Bioagentes Patogênicos, Faculdade de Medicina de Ribeirão Preto, Universidade de São Paulo, Av. Bandeirantes 3900, Ribeirão Preto, SP 14049-900, Brazil
${ }^{2}$ Instituto de Biociências, Universidade Federal de Mato Grosso do Sul, Cidade Universitária, Campo Grande, MS 14049-900, Brazil
${ }^{3}$ Departamento de Biologia, Faculdade de Filosofia, Ciências e Letras de Ribeirão Preto, Universidade de São Paulo, Av. Bandeirantes 3900, Ribeirão Preto, SP 14040-901, Brazil

Received 18 May 2017 - Revised 4 September 2017 - Accepted 25 September 2017

\begin{abstract}
The strong dimorphism in ovary phenotype seen between honey bee queens and workers represents the anatomical fixation of reproductive division of labor. We review the developmental processes by which the divergent ovary phenotypes become established, mainly focusing on the massive programmed cell death (PCD) that destroys most of the ovariole primordia in the worker ovary during larval development. Ovary-specific transcriptome analyses revealed a set of differentially expressed genes associated with PCD, including two long noncoding RNAs. PCD also plays a major role regulating ovarian activity in adult honey bee workers, and a major effect candidate gene mediating this process is Anarchy, previously identified through classical genetics in a rebel worker strain. Finally, we ask how the strong ovary phenotype dimorphism in the genus Apis may have evolved, and we discuss this by contrasting honey bees with the equally eusocial stingless bees. Through a comparison of their mating systems (polyandry versus monandry), as well as comparative data on female and male gonad structure across several families of bees, we propose the hypothesis that the exceptional gonad structure in Apis queens and drones evolved via shared developmental pathways. Furthermore, we suggest that selection on massive sperm production in Apis drones may have been a driving force leading to this exaggerated gonad morphology.
\end{abstract}

honeybee / gonad development / cell death / differential gene expression / meliponids

Where does the spirit of the hive reside? At least to some extent it is in the ovaries of a crowd of bees working in a dark hive (Robert E. Page Jr.)

Corresponding author: K. Hartfelder, klaus@ fmrp.usp.br Manuscript editor: David Tarpy

\section{INTRODUCTION}

With this answer, in response to the question posed by Maurice Materlincks' work The Life of the Bee, ends the remarkable book The Spirit of the Hive (Page 2013). The size of the ovaries, as well as their activity in terms of oogenesis progression, is the main character that distinguishes queens and workers of highly eusocial insects, and a large, active ovary essentially represents 
the fixation of the reproductive primacy of the queen(s) against the thousands of subfertile (non-totipotent) or completely sterile workers living in a colony.

The honey bee, Apis mellifera, is a prime example for such structural and functional queen/ worker differences in the reproductive system, with very large ovaries, each typically consisting of 120-200 serial units, the ovarioles, in the adult queen and small ovaries made up of 2-12 ovarioles each in the worker (Snodgrass 1956; Linksvayer et al. 2011). Furthermore, the sperm storage organ, the spermatheca, is fully developed in the queen, but only a remnant is present in the worker (Snodgrass 1956). In the adult females, these structural differences generated during preimaginal ovary development are also the basis for differences in ovary function or, in other words, for worker sterility versus queen fertility.

In this review, we will primarily focus on the question of ontogenetic mechanisms that govern female gonad development. We start with the preimaginal stages, giving a brief overview on embryonic gonad development, followed by an in-depth description on processes and mechanisms that generate the divergence in gonadal structure during the critical stages for caste differentiation in the larval stages, when the adult ovariole number becomes determined. The subsequent section is dedicated to the regulation of ovarian activity in adult honey bees, especially the question of worker sterility. Throughout these sections, we will emphasize the importance of tissue or organ-specific molecular studies, since global, whole-body gene expression analyses unavoidably merge the developmental dynamics of different organs, making it difficult to arrive at insightful gene regulatory networks for a specific tissue. This is especially the case for the reproductive system, which contains cellular elements of three different embryonic origins, which, most likely, also exhibit differences in their gene regulatory networks. These elements are the germ cells, the mesoderm-derived (somatic) insect gonads and ovarian ducts, and the ectoderm-derived genital imaginal discs. Furthermore, the transcriptomic contribution of the reproductive system likely represents a very small percentage only in wholebody analyses, especially in larvae, where the fat body is the predominant tissue and of prime importance for larval growth.

Questions concerning evolutionary aspects will be addressed by including data on ovarian activity in stingless bees, the only other group of bees that has reached the same level of a highly eusocial organization as the honey bees, and by drawing attention to parallels with the reproductive system of male bees. Males are the neglected gender, not only among bees (Koeniger 2005) but also among social insects in general. Nevertheless, we believe that understanding gonad development and the reproductive biology of males can shed light on questions that may appear enigmatic, such as the extraordinarily high number of ovarioles in Apis queens.

\section{DEVELOPMENTAL BIOLOGY OF THE OVARY}

\subsection{The embryonic gonad}

Except for studies investigating the haplodiploid molecular mechanisms of the sex determination pathway acting in early embryonic stages (Beye et al. 2003; Hasselmann et al. 2008), the embryonic development of honey bees has, until recently, not received nearly as much attention as that of Drosophila. In fact, for thorough information, one must go back to studies done in the early twentieth century (Nelson 1915; Schnetter 1935), followed later by detailed descriptions of embryonic stages (DuPraw 1967; Fleig and Sander 1986, 1988). Fortunately, this has somewhat changed once the fully sequenced honey bee genome became available, making possible in-depth comparisons with Drosophila embryonic development (Cridge et al. 2017). Embryonic development has since came under scrutiny primarily with respect to axial patterning, segmentation and Hox genes (Walldorf et al. 2000; Dearden et al. 2006; Wilson et al. 2010), as well as microRNAs regulating such patterning genes (Freitas et al. 2017). Another line of research addressed zygotic genome activation (Pires et al. 2016). All these studies were driven from the perspective of comparative evolutionary developmental biology. Nonetheless, compared to Drosophila melanogaster, very little is actually 
known about the development of specific organs in A. mellifera.

With respect to gonad development, a major difference to Drosophila is apparent already at a very early step, namely the mode of germ cell determination in the blastoderm stage. While the prospective germ cells in Drosophila become clearly distinguishable at this stage at the posterior pole of the blastoderm embryo, dependent on pole plasm factors (Mahowald 1962), no evidence was found for such pole plasm determinants in the honey bee (Nelson 1915; DuPraw 1967), even though most of the genes encoding pole cell components involved in Drosophila germ cell determination have homologs in the honey bee genome (Dearden et al. 2006). Hence, the mode of germline specification is thought to be quite distinct from that of Drosophila and in fact guided by epigenetic factors (Dearden 2006; Cridge et al. 2017). The next developmental step then is the migration towards and arrival and integration of the primordial germline cells in the somatic (mesodermal) gonad. In the view of complete lack of knowledge for honey bees in this respect, we can only assume that this association may be guided by similar mechanisms as in the Drosophila embryo (Gilboa and Lehmann 2006; Slaidina and Lehmann 2017).

\subsection{Caste-specific ovary differentiation in the larval stages}

The still most comprehensive description on the development of the reproductive system in honey bee larvae dates back to the early twentieth century (Zander 1916), presenting analyses from histological sections of drone, queen, and worker larvae, produced by Prof. Dr. Enoch Zander and two of his doctoral students, Fritz Löschel and Konrad Meier. Unfortunately, this study was published in German and thus is not easily fully appreciated nowadays, but it is outstanding for its excellent illustrative tables ( 6 tables composed of over 100 figures). These figures show the larval gonads positioned bilaterally between the dorsal vessel and parietal fat body in the fifth and anterior part of the sixth abdominal segment. Upon dissection in vivo, they can be localized by the iridescent reflection of their rich tracheal network as elongated banana-shaped structures. In fact, for an embryologist, they do not look too different from the elongated gonads of a day 10-11 mouse embryo. The gonads are apically connected to each other over the dorsal midline, right beneath the dorsal vessel, and at their basal side emerges a string that bilaterally surrounds the midgut and connects the gonads to the ventrally positioned genital imaginal discs (Figure 1). In female larvae, these strings will eventually become the lateral oviducts and, once the larval gut is emptied in preparation for metamorphosis, these strings contract, and the ovaries move ventrally undergoing a $90^{\circ}$ rotation. Thereby, the apical side becomes constricted and will become the anterior, distal part of the ovary, where the future terminal filaments are formed. The basal side of the ovary also becomes constricted and forms the region where the basal ends of the ovarioles merge with the lateral oviduct.

While such descriptive morphological data provide insights on the transformation of the larval ovary into its adult form, they lack information on what is actually going on at the cellular level. In fact, for first instar larvae, the only histological data we are aware of are sections prepared by Cruz-Landim 2009). These indicate that germ cells and somatic cells are already structurally organized as individualized ovarioles, separated from one another by prospective peritoneal sheath cells. For second instar larvae, one of these sections (Cruz-Landim 2009) shows clearly individualized short ovarioles, each with an elongated filament at the apical end. Within these primordial ovarioles, large cells with a spherical nucleus can be distinguished, representing a typical germ cell morphology. Such an early appearance of clearly distinct ovariole primordia is quite different from what is seen in the larval ovary of Drosophila melanogaster, where ovariole primordia become established and clearly separated from each another only in the third (last) larval instar (King 1970), driven by the formation and organization of terminal filament cell stacks (Godt and Laski 1995; Sarikaya et al. 2012).

Until the fourth instar, the ovaries of queen and worker larvae do not yet show major apparent morphological differences with respect to ovariole structure and number (Hartfelder and Steinbrück 

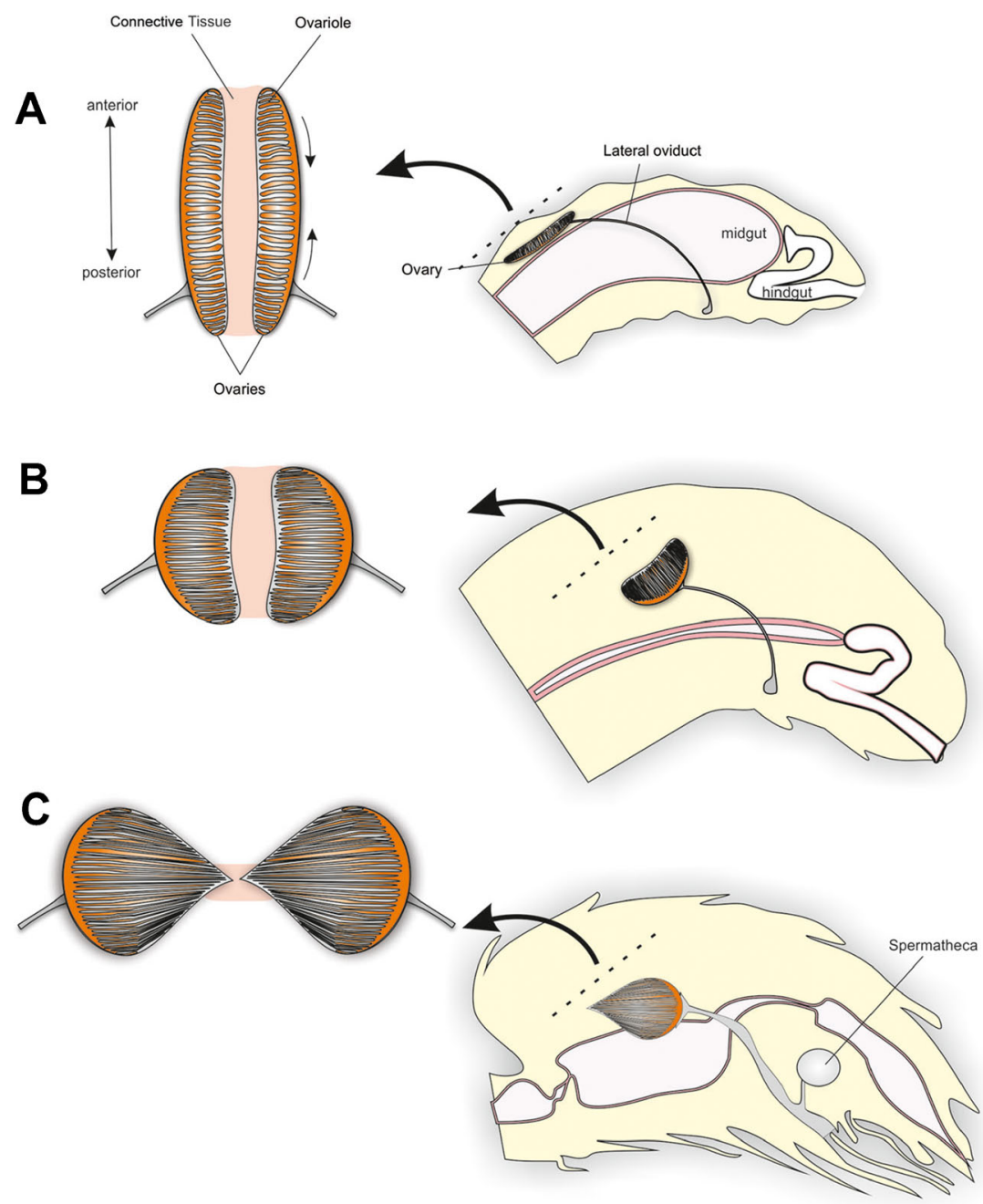

Figure 1. Position and change in format of the honey bee ovaries during postembryonic development. The depicted stages represent $\mathbf{a}$ an early fifth instar larva, $\mathbf{b}$ a queen prepupa, and $\mathbf{c}$ a pharate adult queen. The left column shows the two ovaries as seen when a larva or pupa is dissected dorsally, and the right column shows the relative position of the ovaries in the three developmental stages. Throughout all stages, the two ovaries are connected at their apical sides via a loose band of connective tissue. In these illustrations, we chose to present the situation in queens, but there are no major differences between the two castes, except for ovary and spermatheca size. The schematic drawings of the right column are based on figures from Zander (1916). Artwork was prepared by Douglas Elias Santos.

1997). With the entry into the fifth instar, however, degenerative events gradually become a prominent feature in the ovarioles of worker larvae, as can be inferred already even from their general morphology (Figure 2). This is also the moment when reversal of worker caste fate by transfer of larvae to queen cells becomes increasingly difficult (Dedej et al. 1998).
The degenerative processes in the ovaries of worker larvae are results of programmed cell death (PCD), as detected by TUNEL labeling (Schmidt Capella and Hartfelder 1998), general histological sections (Reginato and Cruz-Landim 2001), and ultrastructure analyses (Hartfelder and Steinbrück 1997). The degenerative process initiates in the germ cell region and is associated with 


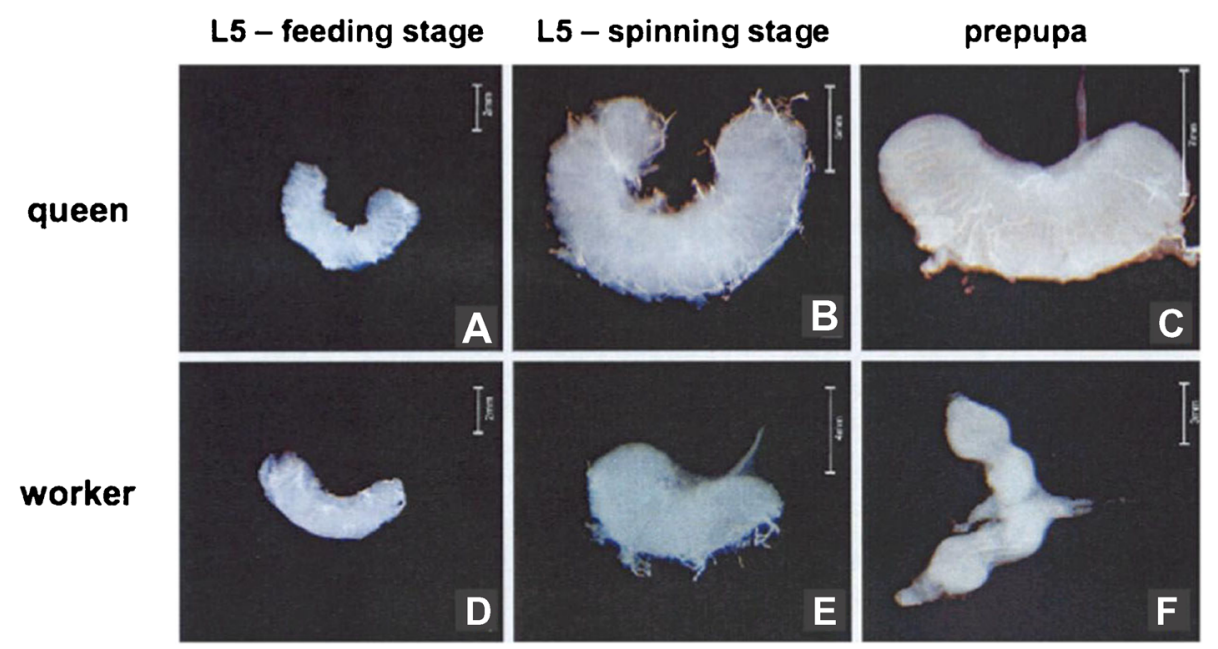

Figure 2. Ovary development in queen $(\mathbf{a}-\mathbf{c})$ and worker $(\mathbf{d}-\mathbf{f})$ larvae of the honey bee. Freshly dissected ovaries from early fifth instar (a, d ), mid fifth instar (b, e), late fifth instar larvae (c), or the entire reproductive system with the two pear-shaped ovaries (f). In $\mathbf{a}-\mathbf{e}$, the apical side is up and the basal is down; in $\mathbf{f}$, the apical side is already contracted and points to the left.

the degradation of a critical germ cell structure, the polyfusome, a structure typical of the polytrophic meroistic insect ovary (Büning 1994). The polyfusome maintains the mitotically dividing sister germ cells cytoplasmatically connected in the format of a germ cell rosette (Hartfelder and Steinbrück 1997). While polyfusomes are maintained in queen ovarioles, their disruption in worker larval ovarioles is due to the disintegration of the actin/spectrin cytoskeleton, and this is considered a critical step for defining the number of ovarioles that will persist in the adult females (Schmidt Capella and Hartfelder 2002). The onset of PCD is seen in the central region of the ovariole primordia where the germ cells are located, and then extends into the apical and basal ends of the ovarioles. Thus, by the entry into the prepupal phase, over $90 \%$ of the ovariole primordia in the worker ovary will become completely degraded (Hartfelder and Steinbrück 1997), and in the pupal stage, the remaining ovariole filaments already permit conclusions regarding adult ovary size.

The critical factor that influences the level of PCD in the fifth instar honey bee ovary is the hemolymph juvenile hormone (JH) titer. Compared to worker larvae, it is by a factor ten higher in queen larvae at the transition from the fourth to the fifth larval instar (Rembold 1987; Rachinsky et al. 1990). It then drops to basal levels in both castes during the beginning of the larval spinning phase, when the brood cells are closed, and only rises again in prepupae, especially so in queens. Topical application of synthetic JH to fourth instar worker larvae inhibited PCD, as seen by a drastic reduction in TUNEL-labeled cells and conservation of the actin/spectrin cytoskeleton in the respective germ cell rosettes (Schmidt Capella and Hartfelder 1998; Schmidt Capella and Hartfelder 2002).

\subsection{Gene expression analyses reveal molecular mechanisms underlying caste-specific ovary development}

To understand the molecular underpinnings of how the caste-specific differences in ovariole number are generated, Dallacqua and Bitondi (2014) investigated the expression of two genes known to be important components of the Drosophila cell death machinery: the genes encoding an apoptotic peptidase activating factor (Apaf)related killer gene (ark) (Rodriguez et al. 1999), an ortholog of the pro-apoptotic mammalian Apaf-1, and buffy, which encodes a member of the B cell lymphoma 2 (Bcl-2) protein family with 

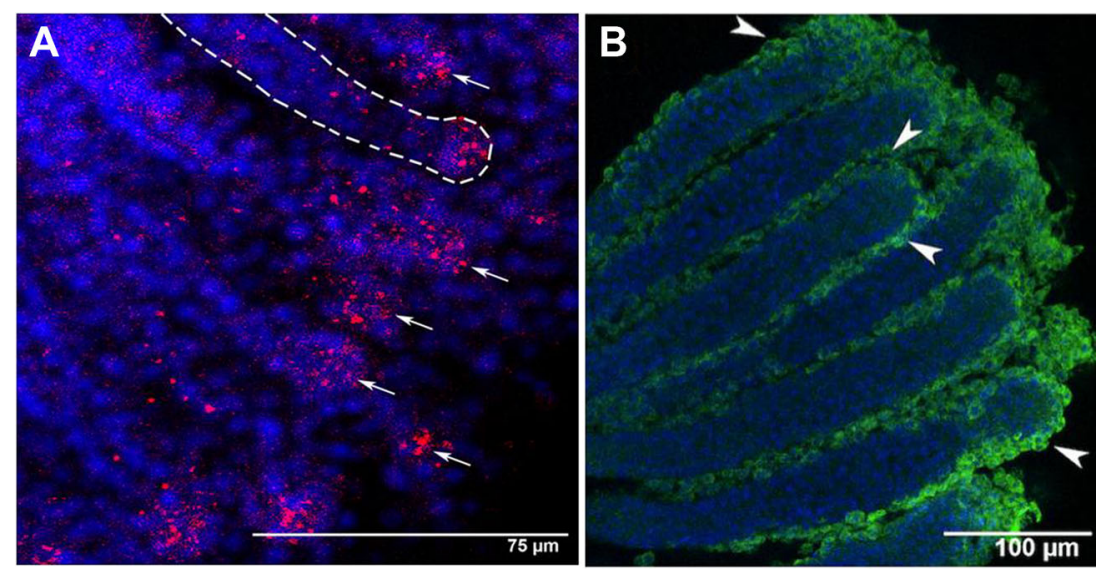

Figure 3. Detection of transcripts of the pro-apoptotic gene ark (a) and the anti-apoptotic gene buffy (b) by in situ hybridization on ovaries of mid fifth instar worker (a) and queen larvae (b ); basal ovariole ends are to the left, apical ends to the right. ark (red) is predominantly expressed near the apical end of the ovarioles (arrows), whereas buffy (green) is strongly expressed in the peritoneal sheaths covering the ovarioles (arrowheads). A white broken line shows the circumference of one of the many ovarioles. Nuclei in blue are marked with DAPI. Modified from Dallacqua and Bitondi (2014).

anti-apoptotic activity (Quinn et al. 2003). The relative quantification of their expression levels in queen and worker larval ovaries showed that pro-apoptotic ark becomes highly expressed in workers, but not in queens, at the end of the fifth instar (prepupae), whereas the expression of the anti-apoptotic buffy increased earlier, at the spinning phase, in the ovaries of queens, and only increased in the following prepupal phase in workers. Furthermore, by fluorescence in situ hybridization, these authors showed strong labeling for the presence of ark RNA in fifth instar worker ovarioles (Figure 3a) in a region where TUNEL labeling had previously indicated the onset of PCD in the germ cell region (Schmidt Capella and Hartfelder 1998). In contrast, buffy RNA appeared strongly associated with cells of the peritoneal sheath that surrounds each ovariole in a queen larval ovary (Figure 3b), appearing as if it were shielding the ovarioles from cell death signals (Dallacqua and Bitondi 2014).

Obviously, we use here the term shielding in a symbolic sense, merely inferred from the localization of these transcripts, but not gene function. Nonetheless, while these two genes are clear bona fide candidates acting within the molecular machinery that establishes the divergent ovary size among the female castes of the honey bee, they appear to be relatively late-acting factors, actually associated with PCD execution but not PCD initiation. Since PCD initiating factors cannot be predicted a priori, and are frequently parts of a cell's general gene regulatory networks, including nutrient sensing, we undertook several approaches to identify possible candidate genes involved in caste-specific ovary differentiation.

The earliest of these molecular approaches was a proteomic one, where we compared protein synthesis patterns in fourth and fifth larval instar ovaries (Hartfelder et al. 1995). We could show that general protein synthesis rates become divergent between the queen and worker ovary shortly after the molt to the fifth instar. Furthermore, characteristic expression differences were noted for two low molecular weight proteins that are likely to be heat shock proteins, and which responded to both $\mathrm{JH}$ and ecdysteroids. No attempts, however, were made at that time to further characterize and sequence these proteins.

All the subsequent approaches were transcriptome analyses of different levels of complexity and throughput, depending on the methods available at their times. The first followed a differential display RT-PCR (DDRT-PCR) protocol and was done to identify ecdysone-responsive genes in the larval honey 
bee ovary (Hepperle and Hartfelder 2001). By that time, the ecdysone response cascade was much better understood than that of $\mathrm{JH}$ (Riddiford et al. 2000; King-Jones and Thummel 2010), and measurements of the hemolymph titer in honey bee queen and worker larvae had indicated a significant timing difference in the ecdysteroid titer peak in spinningphase larvae (Rachinsky and Hartfelder, 1990). From the DDRT-PCR gels, fragments of two genes were cloned and sequenced, one putatively corresponding to a FTZ-F1 homolog and the other to a member of the Cut/CUX1 transcription factor family. Already known by that time as being a component of the ecdysone-mediated transcriptional response, the $\beta F T Z-F 1$ gene is now established as one of the major players that integrate the $\mathrm{JH}$ and ecdysone responses in insect metamorphosis (King-Jones and Thummel 2010), including honey bees (Mello et al. 2014).

More recently and with a fully sequenced honey bee genome at hand, a representational difference analysis (RDA) approach was employed to identify differently expressed genes in honey bee ovaries dissected from fifth instar queen and worker larvae (Humann and Hartfelder 2011). From the suppression-subtractive hybridization libraries, expressed sequence tags (ESTs) of 40 and 32 genes, respectively, were identified as overrepresented in queen and worker ovaries, respectively. Strikingly, $60 \%$ of the ESTs sequenced from the worker library and $28 \%$ of the queen library ESTs represented unpredicted transcripts, i.e., genes that had not been computationally predicted in the honey bee genome, and thus potentially fall into the category of novel genes (Elsik et al. 2014). Validation of the differential expression of 16 of the genes from the two libraries by real-time PCR then confirmed two genes as significantly overexpressed in queen larval ovaries and two in worker ovaries. Among the two queen overexpressed genes, one was $s d r$, a gene encoding a short-chain dehydrogenase/reductase, and the other was an unpredicted gene that we tentatively named Group $11.31 \mathrm{~b}$ based on its genomic scaffold location. Among the workeroverexpressed genes, one was oat, which has ornithine-oxo-acid transaminase activity as a predicted molecular function, and the second was another unpredicted gene named Group11.35a, again according to its genomic scaffold localization (Humann and Hartfelder 2011).

The finding that the $s d r$ gene was overexpressed in queen ovaries was of interest because in the prior DDRT-PCR screen (Hepperle and Hartfelder 2001), we had already obtained EST hits for this gene, for which we could later show that it is strongly ecdysoneresponsive in worker ovaries (Guidugli et al. 2004). The other interesting finding was that the two unpredicted genes with opposite patterns of expression, one being overexpressed in the queen and the other in the worker ovary, mapped genomically to chromosome 11 . Once their complete cDNAs were sequenced, computational analysis revealed that they were likely long noncoding RNAs (Humann et al. 2013).

Long noncoding RNAs (lncRNAs) have come to attention in recent years once next-generation sequencing (NGS) methodologies made it possible to obtain high-throughput and high-density transcriptomes at a large scale. As they have no protein-coding potential, their existence could not be computationally predicted in the assembled genomes. The transcriptomic efforts, especially those done on vertebrate species, including humans, however, revealed the existence of thousands of lncRNA genes (Louro et al. 2009; Mattick 2011; Mattick and Rinn 2015), and functional studies soon demonstrated that these have a plethora of functions, especially so in the finetuning of transcriptional and translational regulation during developmental processes (Mercer et al. 2009; Mattick 2011).

To our knowledge, in honey bees, only four lncRNAs have been identified so far in terms of their possible functions. These are two lncRNAs identified from studies on brain transcriptomes (Sawata et al. 2002, 2004; Kiya et al. 2012) and the two abovementioned IncRNA genes revealed from the ovarian transcriptomes (Humann and Hartfelder 2011), which were subsequently named long noncoding ovary 1 (lncovl) and long noncoding ovary 2 (lncov2). Both turned out to have an intronic location in the sense strand of protein-coding genes, one (lncovl) in a gene of unknown function, only defined by computational prediction, and the other (Incov2) in the honey 
bee homolog of fringe. Fringe proteins are regulators of the Notch signaling pathway, which plays a key role in many cell-cell interaction processes in vertebrate and insect development (Haines and Irvine 2003), including maintenance of the germline stem-cell niche in the Drosophila ovary (Yang et al. 2013) and oogenesis in the honey bee (Duncan et al. 2016). Furthermore, the genomic location of the two lncRNAs and the fringe gene turned out to be eminently interesting, as they all mapped within a major quantitative trait locus (QTL) for ovariole number variation in honey bee workers, previously identified from crosses of wild-type European and Africanized honey bees (Linksvayer et al. 2009) and also from crosses with bees presenting different preferences in pollen hoarding (Graham et al. 2011).

lncovl is of particular interest, not only because it was found overexpressed in association with PCD in the ovaries of worker larvae but also because its transcripts were found to localize with cytoplasmatic granules, indicating that it could functionally be involved in translational regulation (Humann et al. 2013). This cytoplasmatic localization prompted us to study potential lncov1 interaction partners. To do so, we performed a pulldown experiment using lncov1 RNA as bait, followed by a proteomic analysis of associated proteins. One of these called our attention, staphylococcal nuclease domain-containing protein 1, also known as Tudor-SN (Tibério, Cardoso Júnior, Lago, Rosa, Hartfelder, unpublished results). In Drosophila, tudor mutants are sterile (Boswell and Mahowald 1985), and more recently, Tudor proteins were shown to be involved in transcriptional regulation via epigenetic histone modification (Lu and Wang 2013). This shows that we can now gradually build a bridge from the nonhypothesis-driven large-scale analyses to pinpointing genes as bona fide players in the finetuning of PCD in the larval worker ovary. Yet, this bridge still lacks a pillar related to the molecular mechanisms of JH signaling.

Though implicated as a crucial factor in honey bee caste development, immediate $\mathrm{JH}$ effects on larval ovary development were rarely in focus. Rather, as a general morphogenetic hormone, the look generally was on the $\mathrm{JH}$ levels circulating in hemolymph (Rembold 1987; Rachinsky and
Hartfelder, 1990), on how differential feeding of the larvae affected JH synthesis (Rachinsky and Hartfelder, 1990; Bomtorin et al. 2012), and on how JH signaling may integrate with nutrientsensing and metabolic signaling pathways, such as IIS/TOR (Wheeler et al. 2006; Patel et al. 2007; Azevedo and Hartfelder 2008; Wheeler et al. 2014; Hartfelder et al. 2015), EGFR (Kamakura 2011; Hartfelder et al. 2015), and hypoxia (Azevedo et al. 2011; Santos et al. 2016). Furthermore, a mathematical model predicted how the larval feeding regimes and the resultant JH levels would translate into variation in adult ovariole number (Leimar et al. 2012). Other studies already mentioned above had looked at the effects of JH application on PCD in larval ovaries (Schmidt Capella and Hartfelder 1998; Schmidt Capella and Hartfelder 2002), but direct transcriptional JH effects could only be addressed once the paralogous bHLHPAS domain transcription factors methoprenetolerant (Met) and germ cell-expressed (GCE) had been definitively identified as the functional $\mathrm{JH}$ receptor proteins (Charles et al. 2011; Li et al. 2011). When JH is bound to the dimeric JH receptor complex Met/Taiman (Jindra et al. 2013), the Krüppel homolog-1 (Kr-h1) gene is expressed as an early response gene, and in the case of honey bee larvae, its transcript levels were seen to correlate well with the JH titer (Hartfelder et al. 2015).

With this in mind, the $\mathrm{JH}$ response of the set of differentially expressed genes in larval queen and worker ovaries (Humann and Hartfelder 2011) was now assessed by dissecting ovaries of the caste-critical larval stage six hours after the larvae had received a topical application of synthetic JHIII (Lago et al. 2016). The immediate JH response was confirmed by an increase in ovarian $K r-h 1$ expression, and a significant increase in transcript levels was noted for $s d r$ and $h s p 90$, a gene encoding heat shock protein 90 .

As previously mentioned, the $s d r$ gene has sprung up repeatedly and over decades of research as a differentially expressed gene in the larval honey bee ovary, and as directly regulated by the morphogenetic hormones JH (Lago et al. 2016) and makisterone A (Guidugli et al. 2004) [note that makisterone $\mathrm{A}$ is the predominant ecdysteroid moiety in honey bees; Feldlaufer et al. 1985]. This makes the $s d r$ gene an interesting candidate for 


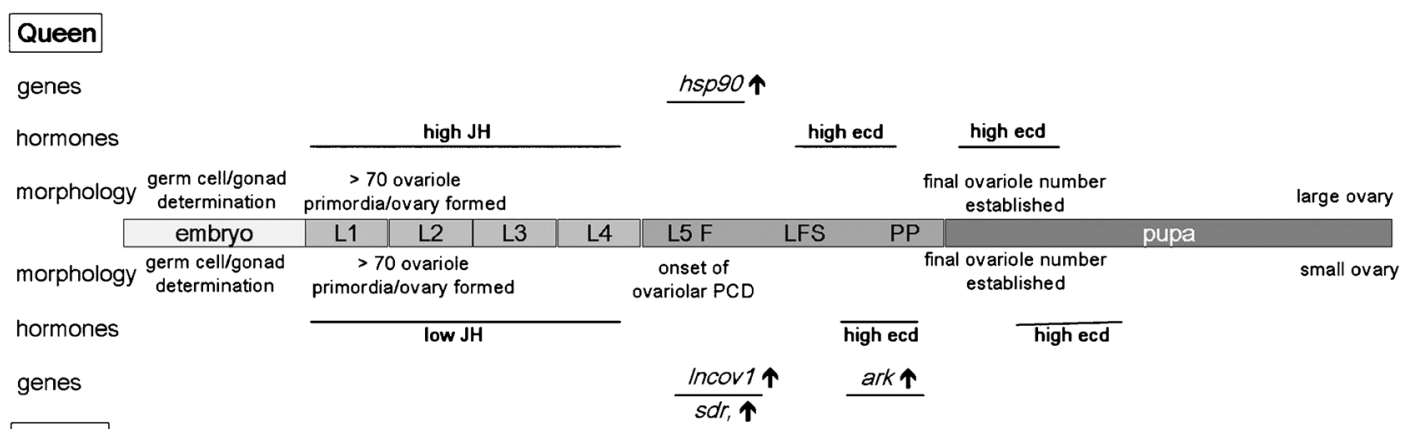

\section{Worker}

Figure 4. Schematic summary of the developmental steps and events as they occur in the embryo, the larval instars L1 to L5 and the pupal stage, leading up to the morphologically distinct ovary phenotypes of adult queens and workers. L5F, L5S, and PP are the feeding, spinning, and prepupal phases of the L5 instar. Shown are the main morphological characters, periods of major differences in juvenile hormone $(\mathrm{JH})$ and ecdysteroid (ecd) hemolymph titer, as well as the phases where certain genes specifically addressed in this review are differentially expressed.

further in-depth functional studies in honey bee caste development. Among the five predicted genes that we could identify in the honey bee genome as encoding members of the SDR family, the one of primary interest has the GenBank entry AAP45005.1. SDRs are a large and phylogenetically ancient family of NAD $(\mathrm{P})(\mathrm{H})$-dependent oxidoreductases, and they exert a variety of functions in the cellular metabolism (Kavanagh et al. 2008). A function that could be of specific interest in the context of honey bee caste development is their sensor function of the cellular redox state, because this could provide a direct link between the hormonal regulation of this $s d r$ gene and the cellular redox potential seen in the honey bee larval fat body (Santos et al. 2016). Furthermore, it could also provide a link to the evolution of sociality in bees, as an $s d r$ homolog was recently identified as differentially expressed in relation to bivoltinism in the non-social bee Tetrapedia cornuta (Araujo et al. 2017, this volume).

The sequential steps and events in the preimaginal development of the honey bee ovary are summarized in Figure 4, illustrating that we have made some headway concerning the molecular underpinnings of honey bee caste development at the tissue-specific level, i.e., the larval ovary. Clearly, there will still be much work to do to put together the puzzle of all the developmental signaling pathways and their interactions, but at least for the two morphogenetic hormone systems, $\mathrm{JH}$ and ecdysteroids, the methoprene-tolerant-Krüppel homolog 1-E93 (MEKRE93) module (Bellés and Santos 2014) is now a good and solid paradigm for the gene regulatory network underlying insect metamorphosis, and this is the context wherein caste development of highly eusocial Hymenoptera is ontogenetically embedded.

Nonetheless, there is still the question on how the dramatic structural difference in the reproductive system of honey bee females has evolved, and this question has recently been addressed in studies that paved the ground for a mechanistic understanding of reproductive bias and worker sterility in adult honey bee and other social Hymenoptera (Duncan et al. 2016; Ronai et al. 2016a). As this topic has recently been thoroughly reviewed (Ronai et al. 2016b), we will only highlight some of these aspects in the next chapter.

\section{OVARIAN ACTIVITY IN ADULT HONEY BEES}

\subsection{Worker sterility-ovary activation and deactivation in adult $A$. mellifera females}

Any researcher working on honey bees has, at least once, included an introductory sentence in a manuscript saying something like in the honey bee, workers are facultatively sterile, while a 
queen can lay over 1000 eggs per day. Of course this describes quite concisely the reproductive division of labor in the colony of these highly eusocial insects. But why are workers facultatively sterile, or better to say subfertile? And has anyone ever counted the number of eggs a queen actually lays per day?

Though subfertile, workers can activate their ovaries in the absence of a queen, and in some exceptional cases, like the Cape honey bee Apis mellifera capensis, the "Clone" in South Africa, and the "anarchistic worker" phenotype originally found in colonies in Australia, they can also do so in the presence of the queen. In Capensis workers and those of the Clone, worker reproduction is associated with a specific switch in developmental modes, i.e., between arrhenotoky and thelytoky (Goudie and Oldroyd 2014; Goudie et al. 2015; Cole-Clark et al. 2017). But examples of arrhenotokous worker reproduction, as in the anarchistic workers, are seen as an exception in the genus Apis. Nonetheless, they are actually a rule in the much more diverse stingless bees, the Meliponini.

In stingless bees, young workers involved in brood cell construction and provisioning of the brood cells lay trophic eggs during the so-called provisioning-oviposition process (POP) (Zucchi et al. 1999). Eaten by the queen, these eggs are an important nutritional resource. Alternatively, the workers can also lay reproductive eggs shortly before cell closure. These eggs will give rise to males, and such worker-produced males actually represent a considerable proportion of the males produced in the colonies. Strikingly, the participation and contribution of the workers in colony reproduction are quite variable among stingless bees (Toth et al. 2004; Velthuis et al. 2005; Hartfelder et al. 2006) and can involve chemical inhibition of ovarian activity (Nunes et al. 2014), similar to honey bees, where queen pheromone has an inhibitory effect (Ronai et al. 2016c). A recent multiple-generation genetics study on Melipona scutellaris colonies showed that workers were the mothers of $23 \%$ of the males, and interestingly, $81 \%$ of these were the offspring of workers from superseded queens (Alves et al. 2009). Thus, daughters from a previous queen do not only live longer but also may reproductively parasitize the nextgeneration workforce (Alves et al. 2009).

So, in distinction to honey bee workers, where oogenesis is blocked at certain steps during follicle development (Tanaka and Hartfelder 2004; Ronai et al. 2015), the ovary of a stingless bee worker goes through the same cycle of activity as that of a queen (Tanaka et al. 2009), the only difference being the number of serial follicles in the ovarioles and the fact that the ovaries of workers undergo cellular degradation as these grow older and become foragers.

Furthermore, stingless bee queens and workers have essentially the same number of ovarioles (Martins and Serrão 2004), but in queens, these are much elongated, and when fully active, the abdomen of the queen is highly physogastric (Engels and Imperatriz-Fonseca 1990). Hence, not the appearance of laying workers in a colony, but rather the subfertile status of honey bee workers, is apparently the exceptional condition among highly eusocial bees. So the question is, what are the underlying molecular and physiological circuitries and what may be the evolutionary causes.

As shown by us (Tanaka and Hartfelder 2004) and Ronai et al. (2015), the occurrence of PCD at certain steps in the oogenesis process creates a mechanism to block reproduction in honey bee workers, and since PCD results from an interplay between pro- and anti-apoptotic factors, this also creates the possibility for reversion of reproductive activity in queenless workers. In their recent comprehensive review, Ronai et al. (2016b) convincingly summarize evidence for evolutionary and mechanistic causes underlying worker sterility in honey bees. They argue that PCD has been incorporated in sequential steps of the ontogenetic program of worker development and reproduction, starting with the inhibition of spermatheca development and degradation of individual ovarioles or germ cells during larval development, followed by selective PCD at four steps during the life cycle of adult workers, including death of germline stem cells and of early germ cell clusters, degradation of early and late follicles, and the loss of entire ovarioles as the workers age and become foragers (Ronai et al. 2016b, 2017). Degradation of late follicles has also been observed in laying workers and in queens of $A$. mellifera (Patrício 
and da Cruz-Landim 2008), and the histological characteristics indicate that the degenerated follicle remnants may be equivalent to the yellow bodies frequently observed in ovaries of social insects in connection with aborted or successful oviposition events (Kelstrup et al. 2014).

PCD in the ovary is not unique to social insects. Rather, it is an adaptive response to unfavorable environmental conditions, allowing insect females to reduce their egg laying rate once there is a shortage of nutrients. Mechanistically, it allows Drosophila females to adjust their reproductive output via insulin/TOR signaling (Pritchett and McCall 2012). Hence, the conclusion is that ovarian PCD in social bees is actually built on an ancestral program allowing reproductive finetuning. This program has become co-opted or, better to say, selectively driven to an extreme in honey bee workers that do not reproduce in the presence of the queen (Ronai et al. 2016b).

An interesting connection between PCD and oogenesis regulation through an evolutionarily conserved developmental signaling pathway, Notch signaling, has recently been evidenced (Duncan et al. 2016). Notch signaling has a repressive effect on the early steps of oogenesis in the worker ovary when a queen is present, and blocking Notch function activates the worker ovary, suggesting that Notch signaling has been coopted into the social circuitry of female reproduction/worker sterility in honey bees. Interestingly, this may actually represent a link also with ovary development in the larval stage, since one of the long noncoding RNAs, lncov2, genomically maps within the intron of the honey bee homolog of fringe/lunatic fringe, which is an activator of Notch signaling and related to FOXO/ insulin signaling in the Drosophila ovary (Yang et al. 2013).

In more general terms, high-throughput analyses designed to distinguish between activated and inactivated ovaries revealed characteristic proteomic differences in workers, indicating regulation via endocrine and neuroendocrine factors (Cardoen et al. 2012). Transcriptomic analyses on ovary activation states in both queens and workers subsequently revealed a highly complex set of differentially expressed genes, including 824 genes shared among the two castes with respect to equivalent ovary activation states (Niu et al. 2014). In an attempt to gain further insights into regulatory pathways, a transcriptomic analysis of microRNAs then confirmed that queens and workers share a set of 19 differentially expressed microRNAs (Macedo et al. 2016), which could be mapped into a regulatory framework that integrated this data with the prior proteomics and transcriptomic analyses.

Interestingly, there is always a certain number of rebel workers present in queenright A. mellifera colonies that defy the queen's inhibitory signals and activate their ovaries. Naturally, their presence has been observed in the context of swarming (Woyciechowski and Kuszewska 2012) and may be related to instability in the interpretation of the queen pheromone signal and also to the absence of brood pheromone (Mohammedi et al. 1998; Maisonnasse et al. 2009). An elevated occurrence of such rebel workers has, however, been noticed in colonies that could be genetically selected as the "anarchistic worker strain," and this has led to the identification of a gene, named Anarchy, associated with this trait (Oldroyd et al. 1994; Oldroyd and Osborne 1999). The Drosophila homolog of Anarchy is a peroxisomal membrane protein (PMP34). Anarchy expression was shown to be a good predictor of the workers' ovary status. Elevated Anarchy expression was shown to be associated with a non-activated ovary state in workers and with the presence of a queen. Furthermore, by in situ hybridization, Anarchy transcripts were found associated with degenerating oocytes, and the RNAi-mediated knockdown of Anarchy function resulted in the upregulation of the anti-apoptotic factor buffy (Ronai et al. 2015), thus putting in evidence a striking and direct connection of this gene with PCD regulation in the ovaries of larval honey bees (see above, Dallacqua and Bitondi 2014).

With a focus on understanding the genomic underpinnings of worker sterility, transcriptome analyses done in a comparison of wild-type workers and workers from the anarchistic strain revealed a set of genes as overexpressed in abdomen of anarchistic workers, including vitellogenin and a gene encoding an enzyme of the AdoHycase superfamily (Thompson et al. 2008). As the latter is considered a candidate 
for modulating the activity of DNA methyltransferases, this finding would again, as already seen in postembryonic development (Kucharski et al. 2008), present a link to epigenetic factors that mediate ovary activity in honey bees (Thompson et al. 2008). Subsequently, by integrating data from such brain and abdomen transcriptomes in a meta-analysis, Sobotka et al. (2016) now present a view on a complex transcriptional regulatory network that they interpret as depicting a social transcriptome underlying worker sterility in honey bees. Such meta-analysis perspectives can provide information on hub genes that interconnect gene regulatory modules and should be useful in heuristically guiding functional studies on this central aspect in honey bee social biology.

\subsection{Vitellogenin and $\mathrm{JH}$ in honey bee reproduction and division of labor}

Notwithstanding the importance of such largescale approaches to the understanding of ovarian function in honey bees, a prime factor for oogenesis undoubtedly is the synthesis of vitellogenin by the fat body and its release into the hemolymph, from where it is then sequestered by the growing oocytes. Vitellogenin uptake occurs by receptor-mediated endocytosis, either via spaces that broaden between follicle epithelial cells (Engels 1973) in a process termed patency or by transepithelial transport (Fleig et al. 1991). The receptor mediating the incorporation of vitellogenin into the oocyte and its subsequent processing into vitellin is the honey bee homolog of the Drosophila yolkless protein. The honey bee vitellogenin receptor ( $\mathrm{VgR}$ ) has been cloned and sequenced, and its expression in ovaries was found to be directly related to the state of ovary activation in both queens and workers. Furthermore, in situ hybridization analysis revealed that the $v g r$ gene is highly expressed in nurse cells composing the trophic chamber, from where the respective mRNA is transported to the growing oocyte (Guidugli-Lazzarini et al. 2008). Since the oocyte nucleus is in the meiotic prophase and, thus, transcriptionally inactive, with the exception of a few genes, this shows that the nurse cells play an important role, not only in previtellogenic but also in vitellogenic growth of the oocyte. While this is, to our knowledge, the only study directed towards the understanding of the molecular underpinnings of vitellogenin uptake, vitellogenin itself is certainly one of the best-studied proteins in the honey bee.

Vitellogenin is a $180-\mathrm{kDa}$ protein (Wheeler and Kawooya 1990) encoded by a single gene (Piulachs et al. 2003), and its functional 3D structure has been predicted by a modeling approach (Havukainen et al. 2011). The levels of vitellogenin in the hemolymph of honey bee queens have been shown to increase during the first days of their adult life cycle and to stay high during the rest of their life, representing up to $60-80 \%$ of the total protein content in hemolymph (Engels 1974; Hartfelder and Engels 1998). Even in queenright non-reproductive workers, the vitellogenin hemolymph levels are elevated while they perform brood rearing tasks within the colony, but then drop as they become foragers. As this transition to foraging behavior is associated with an increase in JH levels (Huang et al. 1994; Huang and Robinson 1996), a mutual repressor circuitry has been proposed and experimentally confirmed as governing this age-related behavioral transition (Amdam and Omholt 2002; Guidugli et al. 2005; Nelson et al. 2007; Marco Antonio et al. 2008).

Two aspects are intriguing in this respect: the fact that (1) $\mathrm{JH}$ triggers the initial increase in vitellogenin levels in both queens and workers as they are about to emerge from their brood cells (Barchuk et al. 2002) and that (2) JH has no further function in the maintenance of the reproductive status in queens (Hartfelder and Engels 1998), but assumes a repressor function on vitellogenin expression in the context of behavioral maturation of workers (Amdam and Omholt 2002). JH is the major gonadotropic hormone in the reproductive cycles of female insects (Wyatt and Davey 1996; Raikhel et al. 2005). Since honey bee queens have no cyclic ovarian activity, but reproduce continuously at high rates, the loss of this $\mathrm{JH}$ function should not be seen as a surprise, as $\mathrm{JH}$ would only be required to initially trigger vitellogenin synthesis in the late pharate adult stage, before they emerge from the brood cell. Furthermore, since A. mellifera workers are suppressed in their reproductive activity by the presence of the queen and larval brood pheromones, a 
long-proposed hypothesis is that $\mathrm{JH}$, once freed from its adult gonadotropic function, may have been evolutionarily co-opted for controlling division of labor among the honey bee workers (Robinson and Vargo 1997).

With its unrivaled status as a model system for social insect biology, a frequently asked question is whether such a vitellogenin/JH regulatory module may also exist and coordinate division of labor in other social insects, and especially so, in other social bees. While JH application experiments provided evidence for such a regulatory module in social wasps (O’Donnell and Jeanne 1993), there is unfortunately little data on actual JH levels in wasp hemolymph, and even less so on vitellogenin synthesis or titers. In fact, the evidence from studies on Polistes paper wasps (Röseler et al. 1984) and tropical, swarm-founding social wasps (Kelstrup et al. 2014) points more towards an association of $\mathrm{JH}$ with reproduction and dominance than with division of labor. $\mathrm{JH}$ levels and ovarian status are strongly correlated in bumblebees (Bloch et al. 2000: Shpigler et al. 2014), and recent data for the stingless bee Melipona scutellaris point in a similar direction (CardosoJúnior et al. 2017). Bombini and Meliponini comprise a branch of eusocial bees within the Corbiculata that is separated from the Apini (Hedtke et al. 2013). Different from honey bees, the workers of bumblebees and stingless bees are reproductively active at some point in their life or in the colony cycle and, thus, the gonadotropic function of $\mathrm{JH}$ should have remained conserved in this branch. This also indicates that the $\mathrm{JH} /$ vitellogenin repressor circuitry, which is so clearly evidenced in the honey bee, may actually be more of an idiosyncrasy of this species and possibly also for the other species of the genus Apis, than representing a general condition in social Hymenoptera.

Actually, this apparent rewiring of the $\mathrm{JH} /$ vitellogenin circuitry in female honey bees may well be related to the queen's polyandrous mating strategy and her exaggerated ovary morphology, with each ovary consisting of well over 100 ovarioles. In this respect, the genus Apis strongly differs from the other bee species, as for most of the Andrenidae, Halictidae, Colletidae, and Melittidae, the number of ovarioles per ovary was found to be three (Iwata 1955; Rozen 1986; Martins and Serrão 2004). Within the corbiculate bees, ovariole numbers are apparently somewhat more variable, but also in these, the Meliponini, Bombini, and Euglossini apparently have only between 4 and 18 ovarioles, with the most variability seen in the queens of stingless bees (CruzLandim et al. 1998; Lisboa et al. 2005). Yet none of these queens comes anywhere close to the honey bee queens, so the question is, what may actually have been the evolutionarily driving force that led to the highly elevated ovariole numbers in the genus Apis? Obviously, one may think that this may be due to the high egg laying rates of honey bee queens compared to those of other social bees, and indeed, for species of stingless bees for which data on daily egg laying rates of queens are available, these do not exceed 30-180 eggs (van Benthem and Velthuis 1995; Martins and Serrão 2004). But these data are for Melipona and Plebeia species, and these do not have really large colonies. Unfortunately, no such data are available for Trigona species, which clearly rival honey bees in terms of colony size. Among the Hymenoptera, similarly high ovariole numbers are only reported for army ants, with over 250 ovarioles per ovary in Eciton schmittii queens (Wheeler 1910), and the champions are driver ants of the genus Dorylus, where over 15,000 ovarioles have been reported for queens (Hölldobler and Wilson 1990).

Strikingly, what these ant species have in common with honey bees is an exceptionally high frequency of multiple matings of their queens (Kronauer et al. 2007), leading to the conclusion that there is at least a correlation between drastically enlarged ovaries and polyandry and that this could reflect trait co-evolution between the female and male sexes in these taxonomically distinct groups.

\subsection{Mating frequency and sperm number - a male sex perspective on female ovary structure in social bees}

The evolution of polyandry, which is a rare trait among social insects in comparison to monandry, has direct implications on intracolony relatedness and kin selection theory, and hence is a long- 
debated issue (Page 1980; Crozier and Page 1985; Boomsma and Ratnieks 1996; Strassmann 2001; Brown and Schmid-Hempel 2003; Kronauer et al. 2007). Furthermore, an ancestral character state reconstruction based on 267 bee, ant, and wasp species provided a strong argument for monandry being ancestral in all of these groups, and that high levels of polyandry are derived, apparently, in one corbiculate bee genus (Apis), one vespine genus (Vespula), and seven distinct lineages of ants (Hughes et al. 2008).

The most frequent explanations of why multiple mating could have evolved in the genus Apis are avoidance of colony losses due to diploid male production, genetic bias of worker specialization, and immune system response variation against disease threats (Page 2013). Nonetheless, the monandrous stingless bees have to cope with the same challenges and there is no evidence that they are worse off. So, a closer look into the mating biology of these two groups of highly eusocial bees may shed some light on the problem.

The mating biology of queens and drones has been in the focus of bee research over decades (Page 1980, Koeniger and Koeniger 1991) and has recently been reviewed in a comprehensive manner by Koeniger et al. (2014). Also, a more general overview on male mating behavior and mating systems of bees has been provided by Paxton (2005), so the reader is referred to these publications for further information. As stingless bees are not only taxonomically diverse, but also vary a lot in terms of their reproductive biology (Vollet-Neto et al. n.d.), a few points of interest shall be addressed here. First, in most stingless bee species, with exception of the genus Melipona, male aggregations and probably also mating occur close to nests where virgin queens are emerging (Michener 1946; Engels and Engels 1984; Engels 1987; Roubik 1990; Cameron et al. 2004). Such aggregations of hundreds to thousands of males form day after day over a certain period and are composed of males from very different locations (Paxton 2000; Kraus et al. 2008), thus guaranteeing genetic diversity. Species of the genus Melipona differ from this general stingless bee pattern, and in this respect, they are more similar to honey bees by using nonresource-based rendezvous sites further distant from the nest (Sommeijer and De Bruijn 1995; van Veen and Sommeijer 2000).

Besides the mating site location, that is, at none-resource-based drone congregation areas in the air (Apis) versus male aggregations close to the colony (stingless bees), the two taxonomic groups differ in another important aspect, i.e., multiple mating (Apis) versus single mating (stingless bees). The mating sign left in the queen's vaginal chamber by a honey bee drone can easily be removed by the subsequent drone (Koeniger and Koeniger 1991; Koeniger et al. 2014), thus permitting a series of sequential copulations during the queen's nuptial flight. This is not the case in stingless bees, where the male leaves its endophallus together with the external genitalia trapped in the queen's vaginal chamber. After returning to the nest, the workers typically remove this mating plug only after a few days, and its persistence in the queen's vaginal chamber for at least one day is in fact important to stimulate egg laying (Melo et al. 2001).

While this difference in mating sign/mating plug function is a mechanistic underpinning of the high mating frequency in the genus Apis, it does not explain the evolution of multiple mating. Rather, from an evolutionary perspective, one would expect considerable differences in selection pressures acting on the males with regard to sperm production, especially when taking into account that both Apis and stingless bee males can mate only once and that in both cases, spermatogenesis ceases during the pupal stage. During adult maturation, all the spermatozoa are or have already migrated to the seminal vesicles and the testes degenerate (Camargo 1984; Koeniger et al. 2014). So, once these males are mature, they are sperm limited, or in other terms, they would have to adjust their sperm production/ejaculate volume during preimaginal development, taking into account the number of the female's expected copulations and the total sperm volume that ends up and remains stored in her spermatheca (Boomsma et al. 2005).

Fortunately, there is good data on actual sperm numbers produced by males and those stored in the spermathecae of females over a wide spectrum of solitary and social bees (Garófalo 1980). In this extraordinary study, sperm counts were made for 

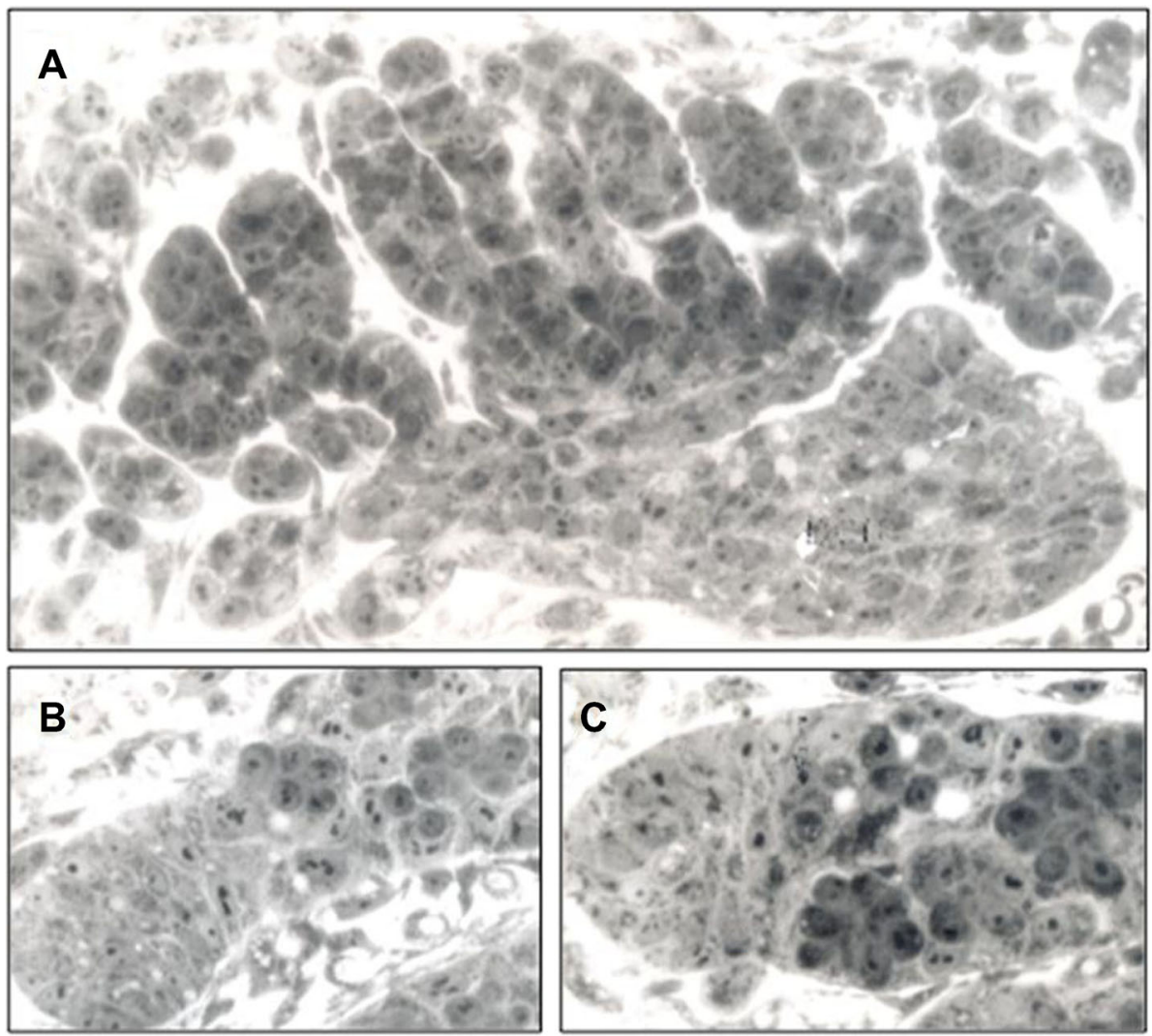

Figure 5. Histological sections of drone larval testes showing testiolar tubules. a Short finger-like testiolar tubules are clearly separated from one another and project from a basal cell mass in testes of third instar larvae. Apical is towards the top. $\mathbf{b}$ Upper end of a testiolar tubule of a fourth instar larvae showing a distinct apical cap region (to the left) followed by small germ cell clusters. c Upper end of a testiolar tubule of a fourth instar larvae with already larger germ cell clusters below the apical cap (to the left).

44 species of bees, comprising Colletidae, Andrenidae, Megachilidae, Anthophoridae, Halictidae, and Apidae, including paired sperm count datasets for both male testes and female spermathecae of 12 species. Furthermore, data from another 22 species from the literature were added (including six paired datasets). This dataset clearly shows that sperm number in the testes/ seminal vesicles of a stingless bee male is practically identical to the sperm number found in the spermatheca of a mated queen. In contrast, in honey bees, these numbers are highly disparate. Sperm counts in drone ejaculates vary from 430,000 for the dwarf honey bee A. florea to over 10 million in A. mellifera, while spermathecal sperm counts range from 1 million (A. florea) to
5 million (A. mellifera) (Baer 2005). Considering a mean mating frequency of 12 in A. mellifera, this means that after mating the queen will discard over $90 \%$ of the sperm she has received, and only a small percentage actually ends up in the spermatheca. These numbers already indicate that there should be an enormous selection pressure on sperm production in Apis males, and this is even further increased by the fact that only about $20-30 \%$ of the spermatozoa in a queen's spermatheca will actually be used to fertilize her eggs (Baer 2005). This would mean that once polyandry had evolved, honey bee drones were likely to come under enormous selection pressure to produce a high number of spermatozoa during a very short time of their 
life, while this should not have been the case for the males of stingless bees.

Evolution of polyandry in the female sex would thus likely be a driving force not only for sperm competition but possibly also for the generation of a high number of tubules that form as testiolar primordia in the larval testes of honey bee drones (Figure 5). At this stage, the testiolar primordia actually look strikingly similar to the ovariole primordia of females (Hartfelder and Steinbrück 1997).

Our hypothesis of a male-driven origin for the exaggerated morphology of the queen ovary in honey bees is, thus, based on (i) the similarity in gonadal structure shared by the two sexes, not only in honey bees but in insects in general (Büning 1994) and (ii) the fact that the differentiation of the insect testis and ovary is apparently guided by the same basic developmental mechanisms (Godt and Tepass 2003; Green and Extavour 2012). A third argument in favor of the hypothesis is the marked congruence in ovariole and testiole number across bee species, as shown in the comparative morphology studies on ovariole (Iwata 1955; Rozen 1986; Cruz-Landim et al. 1998; Martins and Serrão 2004; Lisboa et al. 2005) and testiole numbers (Ferreira et al. 2004).

\section{QUESTIONS FOR THE FUTURE}

Could the selection pressure on high sperm production during a short preimaginal time window, as a consequence of polyandry, have driven developmental mechanisms increasing the number of the drones' testiolar tubules? And is it possible that the same developmental mechanisms that the females share with the drones could have then driven or facilitated evolution towards the high (exaggerated) ovariole number seen in honey bee queens? Asking such questions may at first sight seem awkward but certainly would be in line with the not uncommon cross-sexual transfer of traits due to a shared developmental mechanism (West-Eberhard 2003). While this is as yet a hypothetical conjecture, we believe that it should be now possible to use comparative genomics to look at genes associated with gonad formation in the two sexes of bees and across different taxonomic and social levels. This may then shed light on the question as to why the two honey bee castes differ so drastically in ovary structure and why the genus Apis is so distinct from the other bees in terms of gonad (ovaries and testes) morphology.

\section{ACKNOWLEDGMENTS}

We thank Douglas Elias Santos for producing artwork for this review.

Funding information Financial support was obtained from the Brazilian funding agencies FAPESP (11/03175-5, $2014 / 28147-3$; 2015/05757-5; 17-09128-0) and CNPq (303401/2014-1).

\section{AUTHORS' CONTRIBUTIONS}

KH wrote the review. GJT, DCL, RDP, and MMGB provided original data and discussed subsequent drafts of the manuscript. All authors read and approved the final manuscript.

L'ovaire et ses gènes - les processus de développement sous-jacents à l'établissement et la fonction d'un système reproductif hautement divergent dans les castes de femelles de l'abeille, Apis mellifera

Abeille / développement des gonades / mort cellulaire / expression génique différentielle / Meliponini

Das Ovar und seine Gene - entwicklungssteuernde Prozesse in der Etablierung und Funktion des hochdivergenten Reproduktionssystems der Kasten im weiblichen Geschlecht der Honigbiene, Apis mellifera

Honigbiene / Gonadenentwicklung / Zelltod / differentielle Genexpression / stachellose Bienen

\section{REFERENCES}

Alves, D.A., Imperatriz-Fonseca, V.L., Francoy, T.M., Santos-Filho, P.S., Nogueira-Neto, P., Billen, J., Wenseleers, T. (2009) The queen is dead - long live the workers: intraspecific parasitism by workers in the stingless bee Melipona scutellaris. Mol. Ecol. 18, 4102-4111.

Amdam, G. V., Omholt, S. W. (2002) The regulatory anatomy of honeybee lifespan. J. Theor. Biol. 21, 209228.

Araujo, N.S., Santos, P.K.F., Arias, M.C. (2017) RNA-Seq reveals that mitochondrial genes and long noncoding RNAs may play important roles in the bivoltine 
generations of the non-social Neotropical bee Tetrapedia diversipes. Apidologie. (in press)

Azevedo, S. V., Hartfelder, K. (2008) The insulin signaling pathway in honey bee (Apis mellifera) caste development - differential expression of insulin-like peptides and insulin receptors in queen and worker larvae. J. Insect Physiol. 54, 1064-1071.

Azevedo, S. V., Carantona, O. A. M., Oliveira, T. L., Hartfelder, K. (2011) Differential expression of hypoxia pathway genes in honey bee Apis mellifera L caste development. J. Insect Physiol. 57, 38-45.

Baer, B. (2005) Sexual selection in bees. Apidologie 36, 187-200.

Barchuk, A. R., Bitondi, M. M. G., Simões, Z. L. P. (2002) Effects of juvenile hormone and ecdysone on the timing of vitellogenin appearance in hemolymph of queen and worker pupae of Apis mellifera. J. Insect Sci. 2 , e8.

Bellés, X., Santos, C.G. (2014) The MEKRE93 (Methoprene tolerant-Kruppel homolog 1-E93) pathway in the regulation of insect metamorphosis, and the homology of the pupal stage. Insect Biochem. Mol. Biol. 52, 60-68.

Beye, M., Hasselmann, M., Fondrk, M.K., Page, R.E., Omholt, S.W. (2003) The gene $c s d$ is the primary signal for sexual development in the honeybee and encodes an SR-type protein. Cell, 114, 419-429.

Bloch, G., Borst, D.W., Huang, Z.Y., Robinson, G.E., Cnaani, J., Hefetz, A. (2000) Juvenile hormone titers, juvenile hormone biosynthesis, ovarian development and social environment in Bombus terrestris. J. Insect Physiol. 46, 47-57.

Bomtorin, A. D., Barchuk, A. R., Moda, L. M., Simoes, Z. L. P., 2012. Hox gene expression leads to differential hind leg development between honeybee castes. PLoS One 7, e40111.

Boomsma, J.J., Ratnieks, F.L.W. (1996) Paternity in eusocial Hymenoptera. Philos. Trans. R. Soc. Lond. B 351, 947-975.

Boomsma J.J., Baer B., Heinze J. (2005) The evolution of male traits in social insects, Annu. Rev. Entomol. 50, 395-420.

Boswell, R.E., Mahowald, A.P. (1985) tudor, a gene required for assembly of the germ plasm in Drosophila melanogaster. Cell 43, 97-104.

Brown, M.J. F., Schmid-Hempel, P. (2003) The evolution of female multiple mating in social Hymenoptera. Evolution 57, 2067-2081.

Büning, J. (1994) The Insect Ovary. Chapman \& Hall, London.

Camargo, C.A. (1984) Spermatozoa numbers and migration to the seminal vesicles in haploid and diploid males of Melipona quadrifasciata Lep. J. Apic. Res. 23, 15-17.

Cameron, E.C., Franck, P., Oldroyd, B.P. (2004) Genetic structure of nest aggregations and drone congregations of the Southeast Asian stingless bee Trigona collina . Mol. Ecol. 13, 2357-2364.
Cardoen, D., Ernst, U.R., Boerjan, B., Bogaerts, A., Formesyn, E., de Graaf, D.C., Wenseleers, T., Schoofs, L., Verleyen, P. (2012) Worker honeybee sterility: A proteomic analysis of suppressed ovary activation. J. Proteome Res. 11, 2838-2850.

Cardoso-Júnior, C.A.M., Pereira, R.S., Borges, N.A., de Carvalho, W.J., Leal, W.S., Simões, Z.L.P., Bitondi, M.M.G., Vieira, C.U., Bonetti, A.M., Hartfelder, K. (2017) Methyl farnesoate epoxidase gene expression and juvenile hormone titers in the life cycle of a highly eusocial stingless bee, Melipona scutellaris. J. Insect Physiol.. 101, 185-194.

Charles J-P, Iwema T., Epa V.C., Takaki K., Rynes J., Jindra, M. (2011) Ligand-binding properties of a juvenile hormone receptor, Methoprene-tolerant. Proc. Natl. Acad. Sci. U. S. A.. 108, 21128-21133.

Cole-Clark, M.P., Barton, D.A., Allsopp, M.H., Beekman, M., Gloag, R.S., Wossler, T.C., Ronai, I., Smith, N., Reid, R.J., Oldroyd, B.P. (2017) Cytogenetic basis of thelytoky in Apis mellifera capensis. Apidologie 48, 623-634.

Cridge, A.G., Lovegrove, M.R., Skelly, J.G., Taylor, S.E., Petersen, G.E.L., Cameron, R.C., Dearden, P.K. (2017) The honeybee as a model insect for developmental genetics. Genesis doi: https://doi.org/10.1002 /dvg.23019.

Crozier, R.H., Page, R.E. (1985) On being the right size: male contributions and multiple mating in social $\mathrm{Hy}-$ menoptera. Behav. Ecol. Sociobiol. 18, 105-115.

Cruz-Landim, C., 2009. Abelhas: Morfologia e Função de Sistemas. Editora Unesp, São Paulo.

Cruz-Landim, C., Reginato, R.D., Imperatriz-Fonseca, V.L. (1998) Variation on ovariole number in Meliponinae (Hymenoptera, Apidae) queen's ovaries, with comments on ovary development and caste differentiation. Pap. Avul. Zool. (São Paulo) 40, 289-296.

Dallacqua, R.P., Bitondi, M.M.G. (2014) Dimorphic ovary differentiation in honeybee (Apis mellifera) larvae involves caste-specific expression of homologs of Ark and Buffy cell death genes. PLoS One 9, e98088.

Dearden, P.K. (2006) Germ cell development in the honeybee (Apis mellifera): Vasa and Nanos expression. BMC Dev. Biol. 6, 6.

Dearden, P.K., Wilson, M.J., Sablan, L., Osborne, P.W., Havler, M., et al. (2006) Patterns of conservation and change in honey bee developmental genes. Genome Res. 16, 1376-1384.

Dedej, S., Hartfelder, K., Aumeier, P., Rosenkranz, P., Engels W. (1998) Caste determination is a sequential process: effect of larval age at grafting on ovariole number, hind leg size and cephalic volatiles in the honey bee (Apis mellifera carnica). J. Apic. Res. 37, 183-190.

Duncan, E.J., Hyink, O., Dearden, P.K. (2016) Notch signalling mediates reproductive constraint in the adult worker honeybee. Nat. Commun. 7, 12427.

DuPraw, E.J. (1967) The honey bee embryo. In: Wilt, H.R., Wessels, N.K. (eds.) Methods in Developmental Biology. pp. 183-217. Thomas J. Corwell, New York. 
Elsik, C.G., Worley K.C., Bennett A.K., Beye M., Camara F., et al.; (2014) Honey Bee Genome Sequencing Consortium Finding the missing honey bee genes: lessons learned from a genome upgrade. BMC Genomics 15,86 .

Engels, W. (1973) Das zeitliche und räumliche Muster der Dottereinlagerung in die Oozyte von Apis mellifica . Z. Zellforsch. 142, 409-430.

Engels, W. (1974) Occurrence and significance of vitelllogenins in female castes of social Hymenoptera. Am. Zool. 14, 1229-1237.

Engels, W. (1987) Pheromones and reproduction in Brazilian stingless bees. Mem. Inst. Oswaldo Cruz 82 (Suppl. II), 35-47.

Engels, E., Engels, W. (1984) Drohnen-Ansammlungen bei Nestern der Stachellosen Biene Scaptotrigona postica . Apidologie 15, 315-328.

Engels, W., Imperatriz-Fonseca V.L. (1990) Caste development, reproductive strategies, and control of fertility in honey bees and stingless bees., in: Engels W. (Ed.) Social Insects - an evolutionary approach to castes and reproduction, Springer Verlag, Berlin, pp. 167-230.

Feldlaufer, M.F., Herbert, S.W., Svoboda, J.A., Thompson, M.J., Lusby, W.R. (1985) Makisterone A - the major ecdysteroid from the pupa of the honey bee, Apis mellifera. Insect Biochem.. 15, 597-600.

Ferreira A., Abdalla F.C., Kerr W.E., Cruz-Landim C. (2004) Comparative anatomy of the male reproductive internal organs of 51 species of bees. Neotrop. Entomol. 33, 569-576.

Fleig, R., Sander, K. (1986) Embryogenesis of the honeybee Apis mellifera L. (Hymenoptera: Apidae): An SEM study. Int. J. Morphol. Embryol. 15, 449-462.

Fleig, R., Sander, K. (1988) Honeybee morphogenesis, embryonic cell movements that shape the larval body. Development 103, 525-534.

Fleig, R., Gutzeit, H.O., Engels, W. (1991) Structural organization of ovarian follicle cells in the cotton bug (Dysdercus intermedius) and the honeybee (Apis mellifera ). Cell Tissue Res. 265, 297-305.

Freitas, F.C.P., Pires, C.V., Claudianos, C., Cristino, A.S., Simões, Z.L.P. (2017) MicroRNA-34 directly targets pair-rule genes and cytoskeleton component in the honey bee. Sci Rep 7, 40884

Garófalo, C.A. (1980) Reproductive aspects and evolution of social behavior in bees (Hymenoptera, Apoidea). Rev. Bras. Genet. 3, 139-152.

Gilboa, L., Lehmann, R. (2006) Soma-germline interactions coordinate homeostasis and growth in the Drosophila gonad. Nature 443, 97-100.

Godt, D. Laski, F.A. (1995) Mechanisms of cell rearrangement and cell recruitment in Drosophila ovary morphogenesis and the recruitment of bric-a-brac. Development 121, 173-187.

Godt, D., Tepass, U. (2003) Organogenesis: Keeping in touch with the germ cells. Curr. Biol. 13, R683-685.

Goudie, F., Oldroyd B.P. (2014) Thelytoky in the honey bee. Apidologie 45, 306-326
Goudie, F., Allsopp, M.H., Solignac, M., Beekman, M., Oldroyd, B.P. (2015) The frequency of arrhenotoky in the normally thelytokous Apis mellifera capensis worker and the Clone reproductive parasite. Insect. Soc. 62, 352-333.

Graham, A.M., Munday, M.D., Kaftanoglu, O., Page, Jr. R.E., Amdam, G.V., Rueppell, O. (2011) Support for the reproductive ground plan hypothesis of social evolution and major QTL for ovary traits of Africanized worker honey bees (Apis mellifera L.). BMC Evol. Biol.. 11, 95 .

Green, D.A., Extavour, C.G. (2012) Convergent evolution of a reproductive trait through distinct developmental mechanisms in Drosophila. Dev. Biol. 372 , 120-130.

Guidugli, K.R., Hepperle, C., Hartfelder, K. (2004) A member of the short-chain dehydrogenase/reductase (SDR) superfamily is a target of the ecdysone response in honey bee (Apis mellifera) caste development. Apidologie 35, 37-47.

Guidugli, K. R., Piulachs, M.-D., Bellés, X., Lourenço, A. P., Simões, Z. L. P. (2005) Vitellogenin expression in queen ovaries and in larvae of both sexes of Apis mellifera. Arch. Insect Biochem. Physiol. 59, 211218.

Guidugli-Lazzarini, K.R., do Nascimento, A.M., Tanaka, E.D., Piulachs, M.D., Hartfelder, K., Bitondi, M.G., Simoes, Z.L.P. (2008) Expression analysis of putative vitellogenin and lipophorin receptors in honey bee (Apis mellifera L.) queens and workers. J. Insect Physiol. 54, 1138-1147.

Haines, N., Irvine, K.D. (2003) Glycosylation regulates Notch signaling. Nat. Rev. Mol. Cell Biol. 4, 786-797.

Hartfelder, K., Engels, W. (1998) Social insect polymorphism: hormonal regulation of plasticity in development and reproduction in the honeybee. Curr. Top. Dev. Biol. 40, 45-77.

Hartfelder, K., Steinbrück, G. (1997) Germ cell cluster formation and cell death are alternatives in castespecific differentiation of the larval honey bee ovary. Invertebr. Reprod. Dev. 31, 237-250.

Hartfelder K., Köstlin K., Hepperle C. (1995) Ecdysteroiddependent protein synthesis in caste-specific development of the larval honey bee ovary. Roux's Arch. Dev. Biol. 205, 73-80.

Hartfelder, K., Makert, G.R., Judice, C.C., Pereira, G.A.G., Santana, W.C., Dallacqua, R., Bitondi, M.M.G. (2006) Physiological and genetic mechanisms underlying caste development, reproduction and division of labor in stingless bees. Apidologie 37, 144-163.

Hartfelder, K., Guidugli-Lazzarini, K.R., Cervoni, M.S., Santos, D.E., Humann, F.C. (2015) Old threads make new tapestry - rewiring of signalling pathways underlies caste phenotypic plasticity in the honey bee, Apis mellifera L . Adv. Insect Physiol.. 48, 1-36.

Hasselmann, M., Gempe, T., Schiott, M., Nunes-Silva, C.G., Otte, M., Beye, M. (2008) Evidence for the evolutionary nascence of a novel sex determination pathway in honeybees. Nature 454, 519-522. 
Havukainen, H., Halskau, O., Skjaerven, L., Smedal, B., Amdam, G.V. (2011) Deconstructing honeybee vitellogenin: novel $40 \mathrm{kDa}$ fragment assigned to its $\mathrm{N}$ terminus. J. Exp. Biol. 214, 582-592.

Hedtke, S.M., Patiny, S., Danforth, B.N. (2013) The bee tree of life: a supermatrix approach to apoid phylogeny and biogeography. BMC Evol. Biol. 13, 138.

Hepperle, C., Hartfelder, K., 2001. Differentially expressed regulatory genes in honey bee caste development. Naturwissenschaften 88, 113-116.

Hölldobler, B., Wilson, E.O. (1990) The Ants. Springer, Berlin.

Huang, Z.Y., Robinson, G.E. (1996) Regulation of honey bee division of labor by colony age demography. Behav. Ecol. Sociobiol. 39, 147-158.

Huang, Z.Y., Robinson, G.E., Borst, D.W. (1994) Physiological correlates of division of labor among similarly aged honey bees. J. Comp. Physiol. A. 174, 731-739.

Hughes, W.O.H., Oldroyd, B.P., Beekman, M., Ratnieks, F.L.W. (2008) Ancestral monogamy shows kin selection is key to the evolution of eusociality. Science $\mathbf{3 2 0}$, 1213-1216.

Humann, F.C., Hartfelder, K. (2011) Representational Difference Analysis (RDA) reveals differential expression of conserved as well as novel genes during caste-specific development of the honey bee (Apis mellifera L.) ovary. Insect Biochem. Mol. Biol. 41, 602-612.

Humann, F.C., Tiberio, G.J., Hartfelder, K. (2013) Sequence and expression characteristics of long noncoding RNAs in honey bee caste development - potential novel regulators for transgressive ovary size. PLoS One 8, e 78915.

Iwata, K., 1955. The comparative anatomy of ovary in Hymenoptera. Part I. Mushi 29, 17-34.

Jindra, M., Palli, S.R., Riddiford, L.M. (2013) The juvenile hormone signaling pathway in insect development. Annu. Rev. Entomol. 58, 181-204.

Kamakura, M. (2011). Royalactin induces queen differentiation in honeybees. Nature 473, 478-483.

Kavanagh, K., Jornvall, H., Persson, B., Oppermann, U. (2008) The SDR superfamily: functional and structural diversity within a family of metabolic and regulatory enzymes. Cell. Mol. Life Sci. 65 , 38953906.

Kelstrup, H.C., Hartfelder, K., Nascimento, F.S., Riddiford, L.M. (2014) Reproductive status, endocrine physiology and chemical signaling in the Neotropical, swarmfounding eusocial wasp Polybia micans. J. Exp. Biol. 217, 2399-2410.

King, R.C. (1970) Ovarian Development in Drosophila melanogaster. Academic Press, New York.

King-Jones, K., Thummel, C.S. (2010) Nuclear receptors a perspective from Drosophila. Nat. Rev. Genet. 6, 311-323.

Kiya T, Ugajin A, Kunieda T, Kubo T (2012) Identification of kakusei, a nuclear non-coding RNA, as an immediate early gene from the honeybee, and its application for neuroethological study. Int. J. Mol. Sci. 13, 15496-15509.

Koeniger G. (2005) The neglected sex - males in bees. Apidologie 36, 143.

Koeniger N., Koeniger G. (1991) An evolutionary approach to mating behaviour and drone copulatory organs in Apis. Apidologie 22, 581-590.

Koeniger, G., Koeniger, N., Ellis, J., Connor, L. (2014) Mating Biology of Honey Bees (Apis mellifera). Wicwas Press, Kalamazzo.

Kraus, F.B., Weinhold, S., Moritz, R.F.A. (2008) Genetic structure of drone congregations of the stingless bee Scaptotrigona mexicana. Insect. Soc. 55, 22-27.

Kronauer, D.C., Johnson, R.A., Boomsma, J.J. (2007) The evolution of multiple mating in army ants. Evolution 61, 413-422.

Kucharski, R., Maleszka, J., Foret, S. and Maleszka, R. (2008) Nutritional control of reproductive status in honeybees via DNA methylation. Science 319, 1827-1830.

Lago, D.C., Humann, F.C., Barchuk, A.R., Abraham, J.K., Hartfelder, K. (2016) Differential gene expression underlying ovarian phenotype determination in honey bee, Apis mellifera L. caste development. Insect Biochem. Mol. Biol.. 79, 1-12.

Leimar, O., Hartfelder, K., Laubichler, M.D., Page, R.E., 2012. Development and evolution of caste dimorphism in honeybees - a modeling approach. Ecol. Evol. 2, 3098-3109.

Li, M., Mead, E.A., Zhu, J. (2011) Heterodimer of two bHLH-PAS proteins mediates juvenile hormone induced gene expression. Proc. Natl. Acad. Sci. U. S. A. 108, 638-643.

Linksvayer, T.A., Rueppell, O., Siegel, A., Kaftanoglu, O., Page, R.E., Amdam, G.V. (2009) The genetic basis of transgressive ovary size in honeybee workers. Genetics $183,693-707$.

Linksvayer, T.A., Kaftanoglu, O., Akyol, E., Blatch, S., Amdam, G.V., Page, R.E. (2011) Larval and nurse worker control of developmental plasticity and the evolution of honey bee queen-worker dimorphism. J. Evol. Biol. 24, 1939-1948.

Lisboa, L.C.O., Serrão, J.E., Cruz-Landim, C., Campos, L.A.O. (2005) Effect of larval food amount on ovariole development in queens of Trigona spinipes (Hymenoptera, Apinae). Anat. Histol. Embryol. 34, 179-184

Louro R, Smirnova AS, Verjovski-Almeida S (2009) Long intronic noncoding RNA transcription: Expression noise or expression choice? Genomics 93, 291-298.

Lu, R., Wang, G.G. (2013). Tudor: a versatile family of histone methylation 'readers'. Trends Biochem. Sci. 38, 546-555.

Macedo, L.M.F., Nunes, F.M.F., Freitas, F.C.P., Pires, C.V., Tanaka, E.D., Martins, J.R., Piulachs, M.D., Cristino, A.S., Pinheiro, D.G., Simoes, Z.L.P. (2016) MicroRNA signatures characterizing casteindependent ovarian activity in queen and worker 
honeybees (Apis mellifera L.). Insect Mol. Biol. 25, 216-226.

Mahowald, A.P. (1962) Fine structure of the pole cells and polar granules in Drosophila melanogaster. J. Exp. Zool. 151, 201-215.

Maisonnasse, A., Lenoir, J.-C., Costagliola, G., Beslay, D., Choteau, F., Crauser, D., Le Conte, Y. (2009) A scientific note on $\mathrm{E}-\beta$-ocimene, a new volatile primer pheromone that inhibits worker ovary development in honey bees. Apidologie 40, 562-564.

Marco Antonio, D.S.M., Guidugli-Lazzarini, K.R., do Nascimento, A.M., Simoes, Z.L.P., Hartfelder, K. (2008) RNAi-mediated silencing of vitellogenin gene function turns honeybee (Apis mellifera) workers into extremely precocious foragers. Naturwissenschaften 95, 953-961.

Martins G.F., Serrão J.E. (2004) A comparative study of the ovaries in some Brazilian bees (Hymenoptera; Apoidea). Pap. Avulsos Zool. (São Paulo) 44, 45-53.

Mattick JS (2011) The double life of RNA. Biochimie 93, 8-9.

Mattick, J.S., Rinn, J.L. (2015) Discovery and annotation of long noncoding RNAs. Nat. Struct. Mol. Biol. 22, 5-7.

Mello, T.R., Aleixo, A.C., Pinheiro, D.G., Nunes, F.M., Bitondi, M.M.G., Hartfelder, K., Barchuk, A.R., Simões, Z.L.P. (2014) Developmental regulation of ecdysone receptor $(\mathrm{EcR})$ and EcR-controlled gene expression during pharate-adult development of honeybees (Apis mellifera). Front. Genet. 22, 445.

Melo G.A.R., Buschini M.L.T., Campos L.A.O. (2001) Ovarian activation in Melipona quadrifasciata queens is triggered by mating plug stimulation, Apidologie 32, 355-361

Mercer, T.R., Dinger, M.E., Mattick, J.S. (2009) Long noncoding RNAs: Insights into functions. Nat. Rev. Genet. 10, 155-159.

Michener, C.D. (1946) Notes on the habits of some Panamanian stingless bees (Hymenoptera: Apidea). J. N. Y. Entomol. Soc. 54, 179-197.

Mohammedi, A., Paris, A., Crauser, D., Le Conte, Y. (1998) Effect of aliphatic esters on ovary development of queenless bees (Apis mellifera L.). Naturwissenschaften, 85, 455-458.

Nelson, J.A. (1915) The Embryology of the Honeybee. Princeton University Press, Princeton.

Nelson, C.M., Ihle, K.E., Fondrk, M.K., Page, R.E., Amdam, G.V. (2007) The gene vitellogenin has multiple coordinating effects on social organization. PLoS Biol. 5, e62.

Niu, D., Zheng, H., Corona, M., Lu, Y., Chen, X., Cao, L., Sohr, A., Hu, F., 2014. Transcriptome comparison between inactivated and activated ovaries of the honey bee Apis mellifera L. Insect Mol. Biol. 23, 668-681.

Nunes, T.M., Mateus, S., Favaris, A.P., Amaral, M.F.Z.J., von Zuben, L.G., Clososki, G.C., Bento, J.M.S., Oldroyd, B.P., Silva, R., Zucchi, R., Silva, D.B., Lopes, N.P. (2014) Queen signals in a stingless bee: suppression of worker ovary activation and spatial distribution of active compounds. Sci Rep 4, 7449.

O’Donnell, S., Jeanne, R. (1993) Methoprene accelerates age polyethism in workers of a social wasp (Polybia occidentalis ). Physiol. Entomol. 18, 189-194.

Oldroyd, B.P., Osborne, K.E. (1999) The evolution of worker sterility in honeybees: the genetic basis of failure of worker policing. Proc. R. Soc. B Biol. Sci. 266, 1335-1339.

Oldroyd, B.P., Smolenski, A.J., Cornuet, J.M., Crozier, R.H. (1994) Anarchy in the beehive. Nature 371, 749.

Page Jr., R.E. (1980) Sperm utilization in social insects. Annu. Rev. Entomol. 31 , 297-320.

Page Jr., R.E. (2013) The Spirit of the Hive. Harvard University Press, Cambridge.

Patel, A., Fondrk, M. K., Kaftanoglu, O., Emore, C., Hunt, G., Frederick, K., Amdam, G. V. (2007) The making of a queen: TOR pathway is a key player in diphenic caste development. PLoS One 2, e509.

Patrício, K., da Cruz-Landim, C. (2008) Morphological aspects of cell reabsorption in laying queens and workers of Apis mellifera (Hymenoptera, Apidae). Iheringia Ser. Zool. 98, 421-424.

Paxton, R.J. (2000) Genetic structure of colonies and a male aggregation in the stingless bee Scaptotrigona postica, as revelaed by microsatellite analysis. Insect. Soc. 47, 63-69.

Paxton, R.J. (2005) Male mating behaviour and mating systems of bees: an overview. Apidologie 36, 145156.

Pires, C.V., Freitas, F.C., Dearden, P.K., Simões, Z.L.P. (2016) Transcriptome analysis of honeybee (Apis mellifera ) haploid and diploid embryos reveals early zygotic transcription during cleavage. PLoS One 11, e0146447.

Piulachs, M.D., Guidugli, K.R., Barchuk, A.R., Cruz, J., Simões, Z.L.P., Bellés, X. (2003) The vitellogenin cDNA of the honey bee, Apis mellifera: structural analysis and expression studies. Insect Biochem. Mol. Biol.. 33 , 459-465.

Pritchett, T.L., McCall, K. (2012) Role of the insulin/TOR signaling network in starvation-induced programmed cell death in Drosophila oogenesis. Cell Death Differ. 19, 1069-1079.

Quinn, L., Coombe, M., Mills, K., Daish, T., Colussi, P., Kumar, S., Richardson, H. (2003) Buffy, a Drosophila Bcl-2 protein, has anti-apoptotic and cell cycle inhibitory functions. EMBO J. 22, 3568-3579.

Rachinsky, A., Hartfelder, K. (1990) Corpora allata activity, a prime regulating element for caste-specific juvenile hormone titre in honeybee larvae (Apis mellifera carnica). J. Insect Physiol. 36, 189-194.

Raikhel, A.S., Brown, M.R., Belles, X. (2005) Hormonal control of reproduction. In: Comprehensive Molecular Insect Science, vol. 5. Elsevier, Oxford, pp. 433-491.

Reginato, R.D., Cruz-Landim, C., 2001. Differentiation of the worker's ovary in Apis mellifera L. (Hymenoptera, 
Apidae) during life of the larvae. Invertebr. Reprod. Dev. 39, 127-134.

Rembold, H. (1987) Caste specific modulation of juvenile hormone titers in Apis mellifera. Insect Biochem. 17, 1003-1006.

Riddiford, L.M., Cherbas, P., Truman, J.W. (2000) Ecdysone receptors and their biological actions. Vitam. Horm. 60, 1-73.

Robinson, G.E., Vargo, E.L. (1997) Juvenile hormone in adult eusocial hymenoptera: Gonadotropin and behavioral pacemaker. Arch. Insect Biochem. Physiol. 35, 559-583.

Rodriguez, A., Oliver, H., Zou, H., Chen, P., Wang, X., Adams, J.M. (1999) Dark is a Drosophila homologue of Apaf-1/CED-4 and functions in an evolutionarily conserved death pathway. Nat. Cell Biol. 1, 272-279.

Ronai, I., Barton, D.A., Oldroyd, B.P., Vergoz, V. (2015) Regulation of oogenesis in honey bee workers via programed cell death. J. Insect Physiol. 81, 36-41.

Ronai, I., Oldroyd, B.P., Barton, D.A., Cabanes, G., Lim, J., Vergoz, V. (2016a) Anarchy Is a molecular signature of worker sterility in the honey bee. 33, 134-142.

Ronai, I., Oldroyd, B.P., Vergoz, V. (2016b) The mechanistic, genetic, and evolutionary basis of worker sterility in the social Hymenoptera. Adv. Insect Physiol. 48, 251-317.

Ronai, I., Oldroyd, B.P., Vergoz, V. (2016c) Queen pheromone regulates programmed cell death in the honey bee worker ovary. Insect Mol. Biol. 25, 646-652.

Ronai, I., Allsopp, M.H., Tan, K., Dong, S., Liu, X., Vergoz V., Oldroyd, B.P. (2017) The dynamic association between ovariole loss and sterility in adult honeybee workers. Proc. R. Soc. B Biol. Sci. 284, 20162693.

Röseler, P., Röseler, I., Strambi, A. (1984) Influence of insect hormones on the establishment of dominance hierarchies among foundresses of the paper wasp, Polistes gallicus. Behav. Ecol. Sociobiol. 15, 133142.

Roubik, D.W. (1990) Mate location and mate competition in males of stingless bees (Hymenoptera: Apidae: Meliponinae). Entomol. Gen. 15, 115-120.

Rozen, J.G. (1986) Survey of the number of ovarioles in various taxa of bees (Hymenoptera, Apoidea). Proc. Entomol. Soc. Wash. 88, 707-710.

Santos, D.E., Alberici, L.C., Hartfelder, K. (2016) Mitochondrial structure and dynamics as critical factors in honey bee (Apis mellifera L.) caste development. Insect Biochem. Mol. Biol. 73, 1-11.

Sarikaya, D.P., Belay, A.A., Ahuja, A., Dorta, A., Green, D.A., Extavour, C.G. (2012) The roles of cell size and cell number in determining ovariole number in Drosophila. Dev. Biol. 363 , 279-289.

Sawata, M., Yoshino, D., Takeuchi, H., Kamikouchi, A., Ohashi, K., Kubo, T. (2002) Identification and punctate nuclear localization of a novel noncoding RNA, Ks-1, from the honeybee brain. RNA 8, 772-785.

Sawata, M., Takeuchi, H., Kubo, T. (2004) Identification and analysis of the minimal promoter activity of a novel noncoding nuclear RNA gene, AncR-1, from the honeybee (Apis mellifera L.). RNA 10, 10471058.

Schmidt Capella, I.C., Hartfelder, K. (1998) Juvenile hormone effect on DNA synthesis and apoptosis in castespecific differentiation of the larval honey bee (Apis mellifera L.) ovary. J. Insect Physiol.. 44, 385-391.

Schmidt Capella, I.C., Hartfelder, K. (2002) Juvenilehormone-dependent interaction of actin and spectrin is crucial for polymorphic differentiation of the larval honey bee ovary. Cell Tissue Res. 307, 265-272.

Schnetter, M. (1935) Morphologische Untersuchungen über das Differenzierungszentrum der Embryonalentwicklung der Honigbiene. Z. Morphol. Ökol. Tiere 29, 114-195.

Shpigler, H., Amsalem, E., Huang, Z.Y., Cohen, M., Siegel, A.J., Hefetz, A., Bloch, G. (2014) Gonadotropic and physiological functions of juvenile hormone bumblebee (Bombus terrestris) workers. PLoS One 9, e100650.

Slaidina, M., Lehmann, R. (2017) Quantitative differences in a single maternal factor determine survival probabilities among Drosophila germ cells. Curr. Biol. 27, 291-297.

Snodgrass, R.E. (1956) Anatomy of the Honey Bee. Cornell University Press, Ithaca.

Sobotka, J.A., Daley, M., Chandrasekaran, S., Rubin, B.D., Thompson, G.J. (2016) Structure and function of gene regulatory networks associated with worker sterility in honeybees. Ecol. Evol. 6, 1692-1701.

Sommeijer, N.J., De Bruijn, L.L.M. (1995) Drone congregations apart from the nest in Melipona favosa. Insect. Soc. 42, 123-127.

Strassmann, J. (2001) The rarity of multiple mating by females in the social Hymenoptera. Insect. Soc. 48, $1-13$.

Tanaka, E.D., Hartfelder, K. (2004) The initial stages of oogenesis and their relation to differential fertility in the honey bee (Apis mellifera) castes. Arthropod Struct. Dev. 33, 431-442.

Tanaka, E.D., Santana, W.C., Hartfelder, K. ( 2009) Ovariole structure and oogenesis in queens and workers of the stingless bee Melipona quadrifasciata (Hymenoptera: Apidae, Meliponini) kept under different social conditions. Apidologie 40, 163-177.

Thompson, G. J., R. Kucharski, R. Maleszka, B. P. Oldroyd. (2008) Genome-wide analysis of genes related to ovary activation in worker honey bees. Insect Mol. Biol. 17, 657-665.

Toth E., Queller D.C., Dollin A., Strassmann J.E. (2004) Conflict over male parentage in singles bees. Insect. Soc. 51, 1-11

van Benthem, F.D.J., Imperatrix-Fonseca, C.L., Velthuis, H.H.W. (1995) Biology of the stingless bee Plebeia remota (Holmberg): observations and evolutionary implications. Insect. Soc. 42, 71-87.

van Veen, J.W., Sommeijer, M.J. (2000) Observations on gynes and drones around nuptial flights in the stingless bee Tetragonisca angustula and Melipona bechei 
(Hymenoptera, Apidae, Meliponinae). Apidologie 31, 47-54.

Velthuis H.H.W., Koedam D., Imperatriz-Fonseca V. (2005) The males of Melipona and other stingless bees, and their mothers. Apidologie 36, 169-185

Vollet-Neto, A., Koffler, S., Santos, C.F., Menezes, C., Alves, D.A., Nunes, F.M.F., Hartfelder, K., Imperatriz-Fonseca, V.L. (n.d.) Recent advances in reproductive biology of stingless bees. Insect. Soc.. (submitted).

Walldorf, U., Binner, P., Fleig, R. (2000) Hox genes in the honey bee Apis mellifera. Dev. Genes Evol. 210 , 483492.

West-Eberhard, M.J. (2003) Developmental Plasticity and Evolution. Oxford University Press, Oxford.

Wheeler, W.M. (1910) The Ants: their structure, develoment and behavior. Columbia University Press, New York.

Wheeler, D.E., Kawooya, J.K. (1990) Purification and characterization of honey bee vitellogenin. Arch. Insect Biochem. Physiol. 14, 253-267.

Wheeler, D. E., Buck, N., Evans, J. D. (2006) Expression of insulin pathway genes during the period of caste determination in the honey bee, Apis mellifera. Insect Mol. Biol.. 15, 597-602.

Wheeler, D. E., Buck, N., Evans, J. D. (2014) Expression of insulin/insulin-like signaling and TOR pathway genes in honey bee caste determination. Insect Mol. Biol. 23, 113-121.

Wilson, M.J., Havler, M., Dearden, P.K., (2010) Giant, Krüppel, and caudal act as gap genes with extensive roles in patterning the honeybee embryo. Dev. Biol. 339, 200-211.

Woyciechowski, M., Kuszewska, K. (2012) Swarming generates rebel workers in honeybees. Curr. Biol. 22, 707-711.

Wyatt, G.R., Davey, K.G. (1996) Cellular and molecular actions of juvenile hormone. II. Roles of juvenile hormone in adult insects. Adv. Insect Physiol.. 26, 1-155.

Yang, S.A., Wang, W.D., Chen, C.T., Tseng, T.Y., Chen, Y.N., Hsu, H.J. (2013) Notch/fringe: FOXO/Fringe is necessary for maintenance of the germline stem cell niche in response to insulin insufficiency. Dev. Biol. $382,124-135$.

Zander, E. (1916) Die Ausbildung des Geschlechts bei der Honigbiene (Apis mellifica L.). Z. Angew. Entomol. 3, 1-74

Zucchi, R., Silva-Matos E.V., Nogueira-Ferreira F.H., Azevedo G.G. (1999) On the cell provisioning and oviposition process (POP) of the stingless - nomenclature reappraisal and evolutionary considerations (Hymenoptera, Apidae, Meliponinae). Sociobiology 34, 65-86. 